\title{
Front Matter: Volume 9212
}

, "Front Matter: Volume 9212," Proc. SPIE 9212, Developments in X-Ray Tomography IX, 921201 (17 October 2014); doi: 10.1117/12.2081277

EDIE Event: SPIE Optical Engineering + Applications, 2014, San Diego, California, SPIE. United States 


\title{
PROCEEDINGS OF SPIE
}

\section{Developments in X-Ray Tomography IX}

\author{
Stuart R. Stock
}

Editor

18-20 August 2014
San Diego, California, United States

Sponsored and Published by

SPIE 
The papers included in this volume were part of the technical conference cited on the cover and title page. Papers were selected and subject to review by the editors and conference program committee. Some conference presentations may not be available for publication. The papers published in these proceedings reflect the work and thoughts of the authors and are published herein as submitted. The publisher is not responsible for the validity of the information or for any outcomes resulting from reliance thereon.

Please use the following format to cite material from this book:

Author(s), "Title of Paper," in Developments in X-Ray Tomography IX, edited by Stuart R. Stock, Proceedings of SPIE Vol. 9212 (SPIE, Bellingham, WA, 2014) Article CID Number.

ISSN: 0277-786X

ISBN: 9781628412390

Published by

SPIE

P.O. Box 10, Bellingham, Washington 98227-0010 USA

Telephone +1 3606763290 (Pacific Time) · Fax +1 3606471445

SPIE.org

Copyright $@ 2014$, Society of Photo-Optical Instrumentation Engineers.

Copying of material in this book for internal or personal use, or for the internal or personal use of specific clients, beyond the fair use provisions granted by the U.S. Copyright Law is authorized by SPIE subject to payment of copying fees. The Transactional Reporting Service base fee for this volume is $\$ 18.00$ per article (or portion thereof), which should be paid directly to the Copyright Clearance Center (CCC), 222 Rosewood Drive, Danvers, MA 01923. Payment may also be made electronically through $\mathrm{CCC}$ Online at copyright.com. Other copying for republication, resale, advertising or promotion, or any form of systematic or multiple reproduction of any material in this book is prohibited except with permission in writing from the publisher. The CCC fee code is 0277-786X/14/\$18.00.

Printed in the United States of America.

Publication of record for individual papers is online in the SPIE Digital Library.

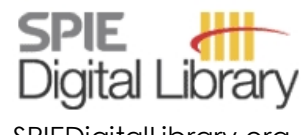

SPIEDigitalLibrary.org

Paper Numbering: Proceedings of SPIE follow an e-First publication model, with papers published first online and then in print and on CD-ROM. Papers are published as they are submitted and meet publication criteria. A unique, consistent, permanent citation identifier (CID) number is assigned to each article at the time of the first publication. Utilization of CIDs allows articles to be fully citable as soon as they are published online, and connects the same identifier to all online, print, and electronic versions of the publication. SPIE uses a six-digit CID article numbering system in which:

- The first four digits correspond to the SPIE volume number.

- The last two digits indicate publication order within the volume using a Base 36 numbering

system employing both numerals and letters. These two-number sets start with 00, 01, 02, 03, 04,

$05,06,07,08,09,0 A, 0 B \ldots$. OZ, followed by 10-1Z, 20-2Z, etc.

The CID Number appears on each page of the manuscript. The complete citation is used on the first page, and an abbreviated version on subsequent pages. Numbers in the index correspond to the last two digits of the six-digit CID Number. 


\title{
Contents
}

\author{
vii Authors \\ ix Conference Committee \\ xi Introduction
}

WELCOME AND OPENING REMARKS

921202 Trends in micro- and nano-computed tomography 2012-2014 [9212-1]

PHASE IMAGING I

921203 Grating interferometry-based phase microtomography of atherosclerotic human arteries (Invited Paper) [9212-2]

921204 Single grating phase contrast imaging for $\mathrm{x}$-ray microscopy and microtomography [9212-3]

921205 Quantitative edge illumination x-ray phase contrast tomography [9212-4]

921206 Grating-based x-ray phase-contrast imaging at PETRA III [9212-5]

NUMERICAL METHODS I

921207 Dictionary learning based low-dose x-ray $\mathrm{CT}$ reconstruction using a balancing principle (Invited Paper) [9212-6]

921208 Practical pseudo-3D registration for large tomographic images [9212-7]

921209 Strategies for efficient scanning and reconstruction methods on very large objects with high-energy $\mathbf{x}$-ray computed tomography [9212-8]

$92120 \mathrm{~A}$ Correction of beam hardening artefacts in microtomography for samples imaged in containers [9212-9]

9212 OB Improving spatial-resolution in high cone-angle micro-CT by source deblurring [9212-10]

\section{APPLICATIONS I}

$92120 \mathrm{C}$ Diffraction computed tomography reveals the inner structure of complex biominerals (Invited Paper) [9212-11]

9212 OD Synchrotron radiation-based characterization of interconnections in microelectronics: recent 3D results [9212-12] 
9212 OE Fast x-ray micro-tomography imaging study of granular packing under tapping [9212-13]

TUBE-BASED TOMOGRAPHY

9212 Ol Brute force absorption contrast microtomography (Invited Paper) [9212-17]

$92120 \mathrm{~J}$ Liquid-metal-jet x-ray tube technology and tomography applications [9212-18]

9212 OK An evaluation to design high performance pinhole array detector module for four head SPECT: a simulation study [9212-19]

9212 OL NanoXCT: development of a laboratory nano-CT system [9212-20]

\section{SYNCHROTRON TOMOGRAPHY}

9212 ON TomoPy: A framework for the analysis of synchrotron tomographic data [9212-22]

$921200 \quad$ P05 imaging beamline at PETRA III: first results [9212-23]

\section{PHASE IMAGING II}

$92120 Q \quad$ Tumors in murine brains studied by grating-based phase contrast microtomography (Invited Paper) [9212-25]

9212 OR X-ray phase contrast tomography from whole organ down to single cells [9212-26]

9212 OS Three-dimensional imaging of human hippocampal tissue using synchrotron radiation- and grating-based micro computed tomography [9212-27]

9212 OT Second order x-ray in-line phase-contrast imaging [9212-28]

$92120 \mathrm{U} \quad$ Evaluation of neural cochlear structures after noise trauma using x-ray tomography (Invited Paper) [9212-29]

\section{APPLICATIONS II}

$92120 \mathrm{~V}$ Submicrometer structure of sea urchin tooth via remote synchrotron microCT imaging (Invited Paper) [9212-30]

9212 OW Characterization of a human tooth with carious lesions using conventional and synchrotron radiation-based micro computed tomography [9212-31]

$92120 X \quad$ Applied $x$-ray computed tomography with high resolution in paleontology using laboratory and synchrotron sources [9212-32] 
9212 OY Three-dimensional registration of synchrotron radiation-based micro-computed tomography images with advanced laboratory micro-computed tomography data from murine kidney casts [9212-33]

$92120 Z$ SEM-based system for 100nm x-ray tomography for the analysis of porous silicon [9212-34]

$921210 \quad$ Apocalypto: revealing lost text with XMT [9212-35]

\section{NUMERICAL METHODS II}

921211 Improving dynamic tomography, through Maximum a posteriori estimation [9212-36]

921213 Dual-energy iterative reconstruction for material characterisation [9212-38]

921214 Iterative reconstruction optimisations for high angle cone-beam micro-CT [9212-39]

POSTER SESSION

921216 High-resolution x-ray computed tomography to understand ruminant phylogeny [9212-42]

921217 Integrated control system environment for high-throughput tomography [9212-43]

921218 Characterization of the CCD and CMOS cameras for grating-based phase-contrast tomography [9212-44]

921219 Image reconstruction for x-ray K-edge imaging with a photon counting detector [9212-45]

9212 1B Carotid plaque characterization using CT and MRI scans for synergistic image analysis [9212-47]

$92121 \mathrm{C} \mathrm{CT} \mathrm{image-based} \mathrm{quantification} \mathrm{of} \mathrm{sub-pixel} \mathrm{diameter} \mathrm{microparticle} \mathrm{accumulations} \mathrm{in}$ tissues using á priori biological information [9212-48]

9212 ID Total variation minimization-based multimodality medical image reconstruction [9212-49]

$9212 \mathrm{lE} \quad$ A study of EM failure in a micro-scale $\mathrm{Pb}$-free solder joint using a custom lab-scale $\mathrm{x}$-ray computed tomography system [9212-50]

$92121 \mathrm{G}$ High performance data management and analysis for tomography [9212-52] 
Proc. of SPIE Vol. $9212921201-6$

Downloaded From: https://www.spiedigitallibrary.org/conference-proceedings-of-spie on 26 Apr 2023 Terms of Use: https://www.spiedigitallibrary.org/terms-of-use 


\section{Authors}

Numbers in the index correspond to the last two digits of the six-digit citation identifier (CID) article numbering system used in Proceedings of SPIE. The first four digits reflect the volume number. Base 36 numbering is employed for the last two digits and indicates the order of articles within the volume. Numbers start with 00, 01, 02, 03, 04, 05, 06, 07, 08, 09, OA, OB...0Z, followed by 10-1Z, 20-2Z, etc.

\author{
Achterhold, Klaus, OX \\ Almer, Jonathan D., OC \\ Anderson, Jill L., $1 \mathrm{C}$ \\ Andersson, Tommy, 0J \\ Arfelli, Fulvia, 05 \\ Audoit, G., OD, OZ \\ Bahadur, Ali, 1B \\ Bai, Ti, 07 \\ Balzer, Matthias, 18 \\ Bartels, Matthias, $\mathrm{OR}$
}

Beckmann, Felix, 03, 06, 00, 0Q, OW, OX, OY, 17 . 18

Bertheau, J., OD

Berti, G., OL

Bidola, Pidassa, OX

Birkbak, Mie, OC

Birkedal, Henrik, OC

Björnsson, Fredrik, OJ

Blair, Justin, 1G

Blevet, P., OD, OZ

Boehnel, Michael, 09

Bruyndonckx, P., 04

Burmester, Hilmar, 06, 00

Burmester, Jörg, 18

Buscema, Marzia, 03

Canon, Richard S., IG

Cao, Yixin, OE

Caselle, Michele, 18

Cattin, Philippe C., 03

Charbonnier, J., OD

Chawla, Nikhilesh, 1E

Chicherova, Natalia, 03

Chilingaryan, Suren, 18

Cloetens, P., OD

Cong, Wenxiang, OT, 19

Costeur, Loic, 16

Cui, Xuelin, 1D

Davis, Graham R., Ol, 10

De Carlo, Francesco, ON

Deslippe, Jack, $1 G$

Deyhle, Hans, 03, OW, OY

Diemoz, Paul C., 05

Djomeni Weleguela, M. L., OD

Dominietto, Marco, $0 Q$, OS

Dose, Thomas, 06, 00

Dreoosi, Diego, 05

Dziadowiec, Iwona, OW

Ehrbar, Stefanie, OY

Endrizzi, Marco, 05
Espes, Emil, 0J

Essiari, Abdelilah, 1G

Fauconneau, M., 14

Ferreira Sanchez, D., OD

Fezzaa, Kamel, OE

Firsching, Markus, 09, OL

Friedrich, Frank, $0 \mathrm{O}$

Frølich, Simon, OC

Gaillard, F-X., $\mathrm{OZ}$

Gehrke, Rainer, 17

Geleta, Matthew, 11

Gergaud, P., OD

Getzin, Matthew, 1B

Gratorp, Christina, 0J

Greving, Imke, 06, 00, 0S, 18

Gürsoy, Doğa, ON

Hagen, Charlotte K., 05

Hammel, Jörg U., 00

Hansson, Björn A. M., OJ

Heinzl, C., OL

Hemberg, Oscar, 0J

Herzen, Julia, 03, 06, 00, 0X, OY, 18

Hexemer, Alexander, $1 \mathrm{G}$

Hieber, Simone E., 03, OQ, OS, OY

Hipp, Alexander, 06, 00, 18

Hodaj, F., OD

Holmberg, A., OL

Holme, Margaret N., 03

Holt, Jeremy, OA

Jacobsen, Chris, ON

Johansson, Göran, OJ

Jorgensen, Steven M., IC

Kastner, J., OL

Kelly, Christopher, OS

Kenesei, Peter, OC

Khimchenko, Anna, OS, OY

Khokhriakov, Igor, 17, 18

Kingston, Andrew M., OA, OB, 11, 13, 14

Kirchhof, R., 06

Kopmann, Andreas, 17, 18

Kou, Binquan, OE

Kovacs, Zsofia, $0 Q$

Kracht, Thorsten, 17

Krenkel, Martin, OR

Kronstedt, Johan, OJ

Krumm, M., OL

Kuo, Willy, OY

Kurtcuoglu, Vartan, OY

Lai, Yu-kun, 10 
Laloum, D., $\mathrm{OZ}$

Laperre, Kjell, 08

Larsson, D. H., OL

Latham, S., 13

Leemreize, Hanna, OC

Lennartz, Michelle R., 1B

Li, Heyang, OB

$\mathrm{Li}$, Jindong, $\mathrm{OE}$

Liddy, Whitney, OU

Lingor, Paul, OR

Liu, Xuan, 08

Longo, Renata, 05

Lopez, Frances C. M., 05

Lorut, F., OD

Lottermoser, Lars, 06, 00, 17, 18

Lytaev, Pavel, 06, 18

MacDowell, Alastair A., $1 G$

Madi, Saaussan, 1B

Mariani, Luigi, OS

Marmaras, Anastasios, OY

Meng, Bo, 19

Mertens, J. C. E., $1 \mathrm{E}$

Meyer, Eric P., OY

Meyer-Loges, Stephan, 18

Micha, J.-S., OD

Mili, Lamine, 1D

Mills, David, OI, 10

Mou, Xuanqin, 07

Müller, Bert, 03, OQ, OS, OW, OY, 16

Müller, Martin, $0 \bigcirc$

Myers, Glenn R., OB, 11, 13, 14

Nachtrab, F., OL

Ogurreck, Malte, 00

Olgac, Ufuk, OY

Olivo, Alessandro, 05

Otendal, Mikael, OJ

Pacheco, Mirian L. A. F., OX

Parkinson, Dilworth Y., IG

Patton, Simon J., $1 \mathrm{G}$

Pauwels, B., 04

Paziresh, Mahsa, 0A, 13

Pfeiffer, Franz, OX

Pickering, Mark R., OK

Plewka, Jörn, 18

Rack, Alexander, OV

Rahman, Tasneem, OK

Ramakrishnan, Lavanya, $1 \mathrm{G}$

Rao, Arhant, 1B

Recur, Benoit, OB, 11, 13, 14

Reims, Nils, 09

Richter, Claus-Peter, OU

Rigon, Luigi, 05

Ritman, Erik L., 1C

Rosin, Paul, 10

Salditt, Tim, OR

Sasov, Alexander, 04, 08

Saverwein, C., OL

Saxer, Till, 03

Schild, Detlev, OR

Schmitz, Rüdiger, 03, 0Q, OS
Schoen, Tobias, 09

Schreyer, Andreas, 06, 18

Schulz, Georg, 03, 0Q, OS, OW, OY, 16

Sheppard, Adrian P., OA, OB, 11, 13, 14

Speier, C., OL

Stock, Stuart R., 02, 0C, OU, OV

Stockmar, Marco K., OX

Sukowski, Frank, 09

Tafforeau, Paul, OX

Tahtali, Murat, OK

Takman, Per, OJ, OL

Tamura, Nobumichi, $1 \mathrm{G}$

Thalmann, Peter, 03, OQ, OS, OY

Thuaire, A., OD

Tierney, Brian L., $1 G$

Töppenwien, Mareike, OR

Torrecillas, R., $\mathrm{OZ}$

Tull, Craig E., $1 \mathrm{G}$

Tuohimaa, Tomi, OJ, OL

Turner, Michael, OB

Uhlmann, N., OL

Ulrich, O., OD

Vercnocke, Andrew J., 1C

Vo, Amanda, OU

Vogelgesang, Matthias, 17, 18

Wang, Ge, 07, 0T, 19, 1B, 1D

Wang, Yujie, OE

Weitkamp, Timm, 03

Whitlon, Donna, OU

Wilde, Fabian, 00

Wintersberger, Eugen, 17

Wu, Junfeng, 07

$\mathrm{Xi}$, Yan, 19

Xia, Chengjie, $\mathrm{OE}$

Xiao, Xianghui, OE, ON, OU

Xu, Qiong, 07

$\mathrm{XU}$, Yiqin, $1 \mathrm{~B}$

Young, Hunter, OU

Yu, Hengyong, 07, 1D 


\section{Conference Committee}

Program Track Chairs

Carolyn A. MacDonald, University at Albany (United States)

Ralph B. James, Brookhaven National Laboratory (United States)

Conference Chair

Stuart R. Stock, Northwestern University (United States)

Conference Program Committee

Felix Beckmann, Helmholtz-Zentrum Geesthacht (Germany)

Graham R. Davis, Queen Mary, University of London

(United Kingdom)

Atsushi Momose, Tohoku University (Japan)

Bert Müller, Basel University Hospital (Switzerland)

Andrew G. Peele, Australian Synchrotron (Australia) and La Trobe University (Australia)

Erik Leo Ritman, Mayo Clinic College of Medicine (United States)

Mark L. Rivers, The University of Chicago (United States)

Ge Wang, Rensselaer Polytechnic Institute (United States)

Session Chairs

1 Phase Imaging I

Stuart R. Stock, Northwestern University (United States)

2 Numerical Methods I

Ge Wang, Rensselaer Polytechnic Institute (United States)

3 Applications I

Bert Müller, Basel University Hospital (Switzerland)

4 Tube-based Tomography

Erik Leo Ritman, Mayo Clinic College of Medicine (United States)

5 Synchrotron Tomography

Graham R. Davis, Queen Mary, University of London

(United Kingdom)

6 Phase Imaging II

Felix Beckmann, Helmholtz-Zentrum Geesthacht (Germany) 
7 Applications II

Ge Wang, Rensselaer Polytechnic Institute (United States)

8 Numerical Methods II

Erik Leo Ritman, Mayo Clinic College of Medicine (United States)

Proc. of SPIE Vol. $9212921201-10$

Downloaded From: https://www.spiedigitallibrary.org/conference-proceedings-of-spie on 26 Apr 2023 Terms of Use: https://www.spiedigitallibrary.org/terms-of-use 


\section{Introduction}

The field of $x$-ray tomography with emphasis on micro- and nano-scale 3D imaging continues to develop rapidly. Many more laboratory and storage-ring based Computed Tomography (CT) systems are in operation, churning out data sets, than there were in August 2012 when the last Developments conference was held. Spectral CT and photon counting CT are examples of rapidly developing modalities. Strategies are becoming increasing sophisticated for rapid, accurate registration of tomography data sets with those of other modalities. Methods for reconstruction with limited data sets (missing angle ranges; small number of projections) and for phase reconstruction are becoming much more accessible.

The field remains vibrant. The editor has identified many more than $10^{3}$ papers on $\mathrm{x}$-ray microCT published annually, and there is great industrial effort which does not produce papers in the open literature. The third generation of tomographers is coming into their own (e.g., students of students of faculty such as Prof. Ulrich Bonse who established this conference). As time passes and a field becomes more mature, it is inevitable that members of this community are lost. Steve Wilkins a longtime proponent of $x$-ray imaging, developer of innovative approaches and former member of the Program Committee, died between Developments meetings. Tom Breunig died suddenly; he has been out of the field for some years but was a key member of the teams doing the first in situ tomography loading experiments of cracked samples and the in vivo microCT of small animals.

The ninth conference in the Developments series filled two entire days (oral presentations) and an evening poster session. There was a stimulating balance between mathematical treatment of reconstructions and of artifact reduction on the

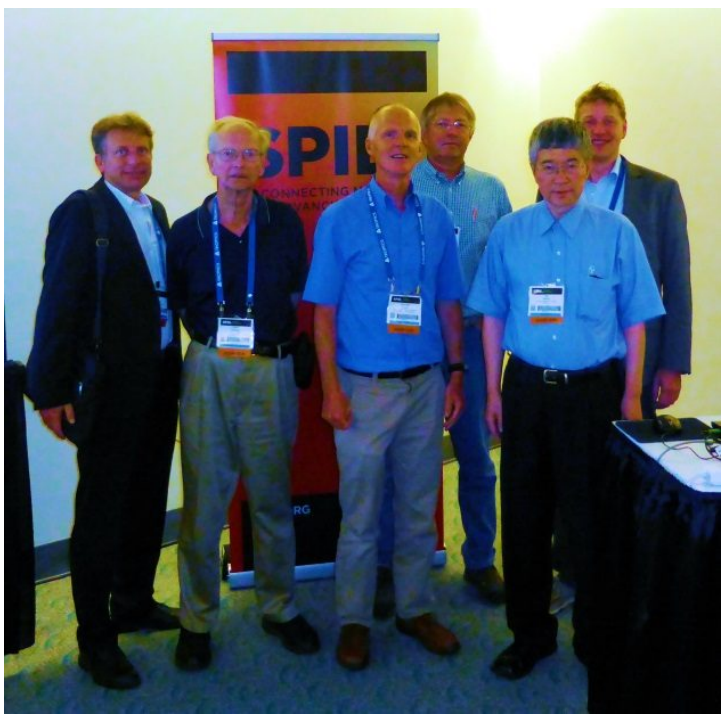

The Program Committee after a session (from left to right): Bert Müller, Erik Ritman, Graham Davis, Stuart Stock, Ge Wang and Felix Beckmann

\author{
and
} one hand and experimental studies and analysis strategies and instrumentation development on the other. The diversity of applications underlined the mature interdisciplinary scope of the conference. The Editor thanks the authors for their excellent talks and papers, invited and contributed; 42 manuscripts from 53 presentations appear in the conference volume. He also thanks the Program Committee for their very important help; two of them reviewed each manuscript. The photograph below shows Committee members after one of the technical sessions. Last, but not least, the SPIE staff provided exemplary support with the program development, the meeting itself and the Proceedings. 
Proc. of SPIE Vol. $9212921201-12$

Downloaded From: https://www.spiedigitallibrary.org/conference-proceedings-of-spie on 26 Apr 2023 Terms of Use: https://www.spiedigitallibrary.org/terms-of-use 